\title{
Effects of skeletal deformities on swimming performance and recovery from exhaustive exercise in triploid Atlantic salmon
}

\author{
Mark D. Powell ${ }^{1,2, *}$, Matthew A. Jones ${ }^{1}$, Maite Lijalad ${ }^{1}$ \\ ${ }^{1}$ School of Aquaculture, Tasmanian Aquaculture and Fisheries Institute, University of Tasmania, \\ Locked Bag 1370 Launceston, Tasmania 7250, Australia \\ ${ }^{2}$ Faculty of Biosciences and Aquaculture, Bodø University College, Bodø 8049, Norway
}

\begin{abstract}
The occurrence of spinal deformity in aquaculture can be considerable, and a high rate of deformity has been suggested in triploid smolts in Tasmania. However, the physiological performance of fish with skeletal deformities has not been addressed. The swimming performance and oxygen consumption of triploid Atlantic salmon smolts with either a vertebral fusion (platyspondyly) or multifocal scoliosis were compared to normal (non-deformed) triploid smolts. Fish with vertebral fusion attained swim speeds similar to normal fish, whereas scoliotic fish were unable to attain comparable swim speeds. Routine and maximum oxygen consumption was higher for deformed fish compared with normal fish, translating into apparent increased routine metabolic scope in vertebral fusion fish, and equivocal scope in scoliotic fish compared with normal controls. Deformed fish developed a lower excess post-exercise oxygen consumption compared to non-deformed fish, suggesting they are either incapable of sustained anaerobic activity or possess an increased recovery capacity. These data suggest that skeletal deformity has differential effects on swimming performance depending upon the type of deformity but imposes a significant metabolic cost on salmon smolts.
\end{abstract}

KEY WORDS: Atlantic salmon · Salmo salar L. · Triploid · Swimming performance - Scoliosis · Platyspondyly $\cdot$ Metabolic rate $\cdot$ Critical swimming speed

\section{INTRODUCTION}

Skeletal deformities are increasingly commonplace in fish culture as modern production requires intensive farming and rapid growth rates of juvenile fish. Somatic growth continues in triploids and flesh quality is maintained over the period when diploid fish are sexually maturing and undergoing associated reduction in flesh quality (Sadler et al. 2000). However, despite the obvious advantages of using triploids, there are a number of problems associated with the commercial production of all-female triploid fish. In some cases deformity rates of up to $30 \%$ have been observed in some Atlantic salmon Salmo salar smolt production, particularly in triploid production
(Jungalwalla 1991, Lijalad 2006, Lijalad \& Powell 2009, H. King pers. comm.). The presence of deformities leads to downgrading of the fish product as well as potential welfare implications of producing deformed fish (Ornsrud et al. 2004). The extent of the deformities reported in salmonid fishes varies around the world, with large numbers of lower jaw deformities (Bruno 1990, Jungalwalla 1991, Hughes 1992, King \& Lee 1993, Lee \& King 1994, Quigley 1995, McGeachy et al. 1996, Branson \& Nieto 1999, Gionechea et al. 1999), shortened operculae (Sutterlin et al. 1987, Baeverfjord et al. 1997), as well as spinal deformities such as scoliosis and lordosis (McKay \& Gjerde 1986). Recently, Deschamps et al. (2008) reported vertebral abnormalities of up to $55 \%$ in some French trout farms. The 
cause of deformity is probably multifactoral (Aunsmo et al. 2008). Although available phosphorus and vitamin levels in the diet (such as vitamins C, E and A) may be inappropriate to support normal bone development in rapidly growing Atlantic salmon (Hughes 1992, King \& Lee 1993, Roberts et al. 2001, Lall \& Lewis-McCrea 2007), no correlation was found between vertebral abnormalities and bone condition (density or mineralization) in trout (Deschamps et al. 2008). However, strong associations have been recently made between vaccination status and the prevalence of spinal deformity in Atlantic salmon (Aunsmo et al. 2008).

Exhaustive exercise is a useful measure of the processes and rate-limiting factors influencing exercise performance in fish (Kieffer et al. 1994, Milligan 1996). Swimming performance is a non-lethal way to assess functional capabilities of fish (see Farrell et al. 1998, Jain et al. 1998). Graded velocity tests, allowing the determination of critical swimming speed ( $\left.U_{\text {crit }}\right)$, have been well-validated as tests of fish performance (Farlinger \& Beamish 1978, Beamish et al. 1989, Reidy et al. 1995, Jain et al. 1997). Indeed, the $U_{\text {crit }}$ test has been used to assess a number of health indices (Jain et al. 1998, Wagner et al. 2003, Tierney \& Farrell 2004, Tierney et al. 2005), as well as the effects of triploidy (Small \& Randall 1989, Stillwell \& Benfey 1996, Hyndman et al. 2003). Most of these tests have revealed that disease impairs repeat swimming performance, with few differences being detected between diploids and triploids (Lijalad \& Powell 2009). However, to our knowledge the effects of skeletal (spinal) deformity on swimming performance have not been examined in Atlantic salmon.

The aim of the present study was to assess the physiological impact of 2 types of spinal skeletal deformity that occurred in a population of triploid Atlantic salmon smolts. We used critical swimming tests to assess physiological performance, and assessed anaerobic capacity using exhaustive exercise and subsequent recovery. Comparisons between triploid and diploid fish from the same population have been made (Lijalad \& Powell 2009), with no apparent significant differences in performance; therefore in the present study, comparisons are confined to deformed and nondeformed triploid fish.

\section{MATERIALS AND METHODS}

Experimental fish and husbandry conditions. A population of 300 sibling, female, triploid, Atlantic salmon Salmo salar smolts were obtained from the Salmon Enterprises of Tasmania (SALTAS) hatchery (Wayatinah, Tasmania), where triploidy was induced by hydrostatic-pressure treatment of fertilised eggs
(Johnstone et al. 1991, Jungalwalla 1991). All-female populations were produced by fertilising the eggs of normal females with milt from sex-reversed genotypic females. All fish were transferred to the School of Aquaculture, University of Tasmania, Launceston, and were maintained in a single $1800 \mathrm{l}$ fibreglass tank within a partially recirculating freshwater (total hardness $37.4 \pm 5.4 \mathrm{mg} \mathrm{l}^{-1} \mathrm{CaCO}_{3 i}\left[\mathrm{Ca}^{2+}\right]$ and $\left[\mathrm{Mg}^{2+}\right]$ were 0.24 and $0.08 \mathrm{mmol}^{-1}$, respectively) system, at a temperature of $15^{\circ} \mathrm{C}\left( \pm 1^{\circ} \mathrm{C}\right.$ range). They were held in this system for at least 1 mo prior to experimentation. Fish were fed to satiation daily with a commercial salmon food (HP Atlantic salmon $3 \mathrm{~mm}$, approx. $47 \%$ protein and $26 \%$ lipid). Food was withheld for $24 \mathrm{~h}$ prior to experimentation to avoid any confounding effects of digestion on metabolic rate or exercise performance (Ross et al. 1992, Alsop \& Wood 1997).

From the initial population, fish with 2 main visible skeletal deformities, a spinal vertebral fusion (platyspondyly) and a multifocal lateral spinal curvature (scoliosis) (see Fig. 1), were separated for the present study along with a group of apparently normal individuals. Other fish with deformities and normal fish (diploid and triploids) were used in other studies. Separation occurred 2 wk prior to use and the subjects were maintained in a second $1800 \mathrm{l}$ fibreglass tank supplied with partially recirculating freshwater at $15^{\circ} \mathrm{C}\left( \pm 1^{\circ} \mathrm{C}\right.$ range), and fed to satiation on the same diet. Four fish exhibiting each deformity (mean \pm SE mass and fork length respectively in fish with scoliosis: $132.0 \pm 6.5 \mathrm{~g}, 21.6 \pm$ $0.8 \mathrm{~cm}$, vertebral fusion: $116.4 \pm 10.7 \mathrm{~g}, 19.1 \pm 1.0 \mathrm{~cm}$ ) and 7 apparently normal fish (mean \pm SE mass, $120.6 \pm$ $9.4 \mathrm{~g}$, and fork length, $22.0 \pm 0.5 \mathrm{~cm}$ ) were used for experimental testing.

Ploidy confirmation. The ploidy status of the triploid fish was confirmed by determining the mean erythrocyte nucleus length (ENL; Benfey et al. 1984) using airdried blood smears stained with haematoxylin. ENL was measured in 10 randomly selected red blood cells using an image analysis program (UTHSCSA Image Tool program; anonymous ftp//maxrad6.uthscsa.edu). Mean ENL values were determined for each fish and frequency histograms of mean ENL values from triploid fish were compared to those of sibling diploid fish. The maximum ENL value observed for diploid fish represented the critical mean ENL value (Thomas \& Morrison 1995). All fish used had a mean ENL value greater than the maximum diploid mean and were assumed to be triploids.

Swimming performance. Atlantic salmon were individually removed from the holding tank and taken to stage 3 anaesthesia (Summerfelt \& Smith 1990) with $50 \mathrm{ppm}$ clove oil (Aurona) for length measurements and to facilitate placement into a $220 \mathrm{l}$ Brett-style swim tunnel. Water flow was generated by a Collins $15 \mathrm{~cm}$ 
centrifugal pump $(5.5 \mathrm{~kW})$ with a variable speed drive controlled by a SPEECON 7300PA (Teco) inverter calibrated prior to the experiment in order to deliver controlled water velocities with a flowmeter (Meister DHTF, Meacon) fixed near the exit of the swim chamber. The upstream grid ensured a laminar and uniform flow over the cross-section of the chamber. A plastic mesh screen was positioned at the back of the swimming chamber to retain the fish within the swimming section of the tunnel. The front portion of the swim chamber was covered by a black plastic sheet that stimulated the fish to swim by keeping its head in the dark part of the chamber (Oakland et al. 1997). The whole system was thoroughly flushed with fresh (system) water between experiments. Water temperature in the tunnel fluctuated $\pm 1^{\circ} \mathrm{C}$ during each swimming experiment.

Once in the swim chamber, fish were allowed to recover for $45 \mathrm{~min}$ in aerated stationary water. After the recovery period, salmon were given a conditioning swim as suggested in Jain et al. (1997) that consisted of an abbreviated step velocity test. Water speed was increased in regular increments of 0.15 body lengths (BL) $\mathrm{s}^{-1}$ every 2 min until the fish was unable to swim faster and rested on (perpendicular to the water flow and pinned against) the grid at the rear of the swimming chamber. The conditioning swim was intended to eliminate the potential training effect observed with naïve fish on a second $U_{\text {crit }}$ test (Farlinger \& Beamish 1978, Jain et al. 1997) and also to provide an index of individual performance to set the subsequent ramp-critical speed $\left(U_{\text {crit }}\right)$ tests (Jain et al. 1997). Fish then recovered overnight (16 to $18 \mathrm{~h}$ ) in aerated stationary water.

All experiments were started between 09:00 and 10:00 h. Fish were subjected to a ramp- $U_{\text {crit }}$ test as described by Jain et al. (1997). The ramp- $U_{\text {crit }}$ protocol produces values for $U_{\text {crit }}$ similar to the more standard $U_{\text {crit }}$ testing protocol in which the longer time intervals are used from the onset of the test (Jain et al. 1997). For ramp- $U_{\text {crit }}$ testing, each fish was brought up to approximately $75 \%$ of the maximum speed achieved in the conditioning swim using 5 min increments of $0.15 \mathrm{BL} \mathrm{s}^{-1}$. Following this, 20 min increments of $0.15 \mathrm{BL} \mathrm{s}^{-1}$ were given until the fish reached exhaustion. Exhaustion was judged to have occurred when the fish failed to move from the rear grid for a period of at least $20 \mathrm{~s}$. $U_{\text {crit }}$ was calculated according to the following equation (Brett 1964):

$$
U_{\text {crit }}=U_{\mathrm{f}}+\left[U_{\mathrm{i}}\left(t_{\mathrm{f}} / t_{\mathrm{i}}\right)\right]
$$

where $U_{\text {crit }}$ is in $\mathrm{BL} \mathrm{s} \mathrm{s}^{-1}, U_{\mathrm{f}}$ is the water velocity of the last fully completed increment $\left(\mathrm{BL} \mathrm{s}^{-1}\right), U_{\mathrm{i}}$ is the water velocity increment $\left(\mathrm{BL} \mathrm{s} \mathrm{s}^{-1}\right), t_{\mathrm{f}}$ is the time spent at fatigue velocity (min) and $t_{\mathrm{i}}$ is the time period for each completed water velocity increment (min).
After a 45 min recovery period in stationary water, a second identical ramp- $U_{\text {crit }}$ test was given to determine $U_{\text {crit2. }}$. The repeat $U_{\text {crit }}$ protocol was chosen since healthy salmonids are capable of repeating exhaustive swimming after as little as a 40 min recovery (Farrell et al. 1998, Jain et al. 1998, Tierney \& Farrell 2004). A recovery ratio (RR) was calculated between the second and first $U_{\text {crit }}$ tests $\left(U_{\text {crit } 2}: U_{\text {crit } 1}\right)$. Swimming velocities were not corrected for the solid blocking effect because the cross-sectional area of the fish was no greater than $10 \%$ of the cross-sectional area of the swimming chamber (Jones et al. 1974).

Recovery from exhaustive exercise. Following the swim tunnel experiment, each fish was individually transferred to a black acrylic respirometer (mean \pm SEM volume, $2.14 \pm 0.01 \mathrm{l}$ ) and supplied with recirculating freshwater at $15^{\circ} \mathrm{C}\left( \pm 1^{\circ} \mathrm{C}\right.$ range $)$ for overnight recovery (16 to $18 \mathrm{~h}$ ). The following day, the water flow through the box was stopped for $10 \mathrm{~min}$, and $3 \mathrm{ml}$ water samples were removed from the outlet of the boxes at Time 0 and after $10 \mathrm{~min}$, after which the water flow to the respirometer chambers was restored. The partial pressure of oxygen $\left(\mathrm{pO}_{2}\right)$ of these samples was immediately determined by injecting the samples into a $\mathrm{pO}_{2}$ electrode (1302 electrode in a thermostatically controlled MC100 cell; Strathkelvin Instruments) connected to a Strathkelvin Instruments model 782 oxygen meter and calibrated daily using a $2 \% \mathrm{NaSO}_{3}$ (zero) solution and air-saturated water (155 mm Hg). Following the resting measurement, fish were exercised individually to exhaustion by manual chasing for 5 min in a shallow circular tank (200 l) containing 601 of isothermic hyperoxic ( $120 \%$ air saturation) water (Altimiras et al. 2002). This method consistently results in exhausted fish. Exhaustion was defined in the present experiment as the point at which the fish stopped swimming and were unresponsive to prodding; this generally required $5 \mathrm{~min}$ of intense chasing. After their individual exercise bouts, fish were immediately returned to their respective respirometer boxes and oxygen consumption measurements were taken as described above. From these data, routine and maximum oxygen consumption $\left(\mathrm{MO}_{2 \text { rout }}\right.$ and $\mathrm{MO}_{2 \max }$ in $\mu \mathrm{mol} \mathrm{O}_{2} \mathrm{~g}^{-1} \mathrm{~h}^{-1}$ ) rates (post-exhaustive exercise) were determined using the formula:

$$
\mathrm{MO}_{2}=\left(\mathrm{pO}_{2 \mathrm{i}}-\mathrm{pO}_{2 \mathrm{f}}\right) V_{\mathrm{b}} \alpha W^{-1} \Delta t^{-1}
$$

where $\mathrm{pO}_{2 \mathrm{i}}$ and $\mathrm{pO}_{2 \mathrm{f}}$ are the initial (Time 0) and final values of $\mathrm{pO}_{2}(\mathrm{~mm} \mathrm{Hg}), V_{\mathrm{b}}$ is the volume (l) of water in the black box, $\alpha$ is the solubility coefficient of water ( $\mu \mathrm{mol} \mathrm{l^{-1 }} \mathrm{mm} \mathrm{Hg}^{-1}$; after Boutilier et al. 1984, Cameron 1986), $W$ is the mass $(\mathrm{g})$ of the fish, and $\Delta t$ is the elapsed time (h). Measurements of background oxygen consumption without fish in the boxes revealed no changes in the dissolved oxygen concentration during 
a 20 min recording period. The rate of oxygen transfer from the air to the unsealed respirometer chamber was measured at $0.183 \mathrm{~mm} \mathrm{Hg} \mathrm{O}$ over the $10 \mathrm{~min}$ measurement period. This value was therefore used to correct $\mathrm{pO}_{2}$ measurements during respiratory experiments. After the second measurement of oxygen consumption, the water flow was reinstated to the respirometer box and fish were allowed to recover with oxygen consumption rates being determined from $\mathrm{pO}_{2}$ measurements taken using the methods outlined above at 5, 15, 30, 45, 60, 120, 180, 240 and $480 \mathrm{~min}$ following exercise. Following recovery the fish were terminally anaesthetised with an overdose of clove oil and the carcasses frozen at $-20^{\circ} \mathrm{C}$ for later X-ray determination of skeletal deformity. The area under the curve bounded by the maximum oxygen consumption rate, routine consumption rate and the point at which the recovery curve intercepted the routine oxygen consumption was determined by integration to determine an excess post-exercise oxygen consumption (EPOC) for each individual.

In the present study, routine oxygen consumption (measured consistently at the same time each day) was used as a measure of minimum oxygen consumption due to the difficulty in obtaining accurate standard oxygen consumptions for fish. Metabolic rate is expressed in terms of oxygen consumption. A routine metabolic scope for activity ( $\mu$ mol $\mathrm{O}_{2} \mathrm{~g}^{-1} \mathrm{~h}^{-1}$ ) was therefore calculated as maximum oxygen consumption $\left(\mathrm{MO}_{2 \max }\right)$ minus routine oxygen consumption $\left(\mathrm{MO}_{2 \text { rout }}\right)$ rather than standard metabolic rate.

Assessment of skeletal deformity. Confirmation and magnitude of the skeletal deformity was determined for each fish by X-ray. Fish were X-rayed in a lateral position for determination of the location and severity of the vertebral compression and/or vertebral fusion while scoliotic fish were X-rayed dorso-ventrally to determine the points of spinal curvature using a Tanka X-ray unit MFG. Images were developed on Kodak Industrex AA400 film after Thomas et al. (2002).

Statistical analysis. Due to the high degree of variation and individual characteristics of each skeletal deformity, data are presented for individuals. However, statistical comparisons were made between means from each group using 1-way ANOVA. Where significant differences were found, individual means were isolated using Bonferroni-corrected multiple comparison tests. Values of $\mathrm{p}<0.05$ were considered to be significant.

\section{RESULTS}

Variation in the presentation of the 2 deformities studied was high (Fig. 1), giving rise to a range of differing responses to swimming performance and
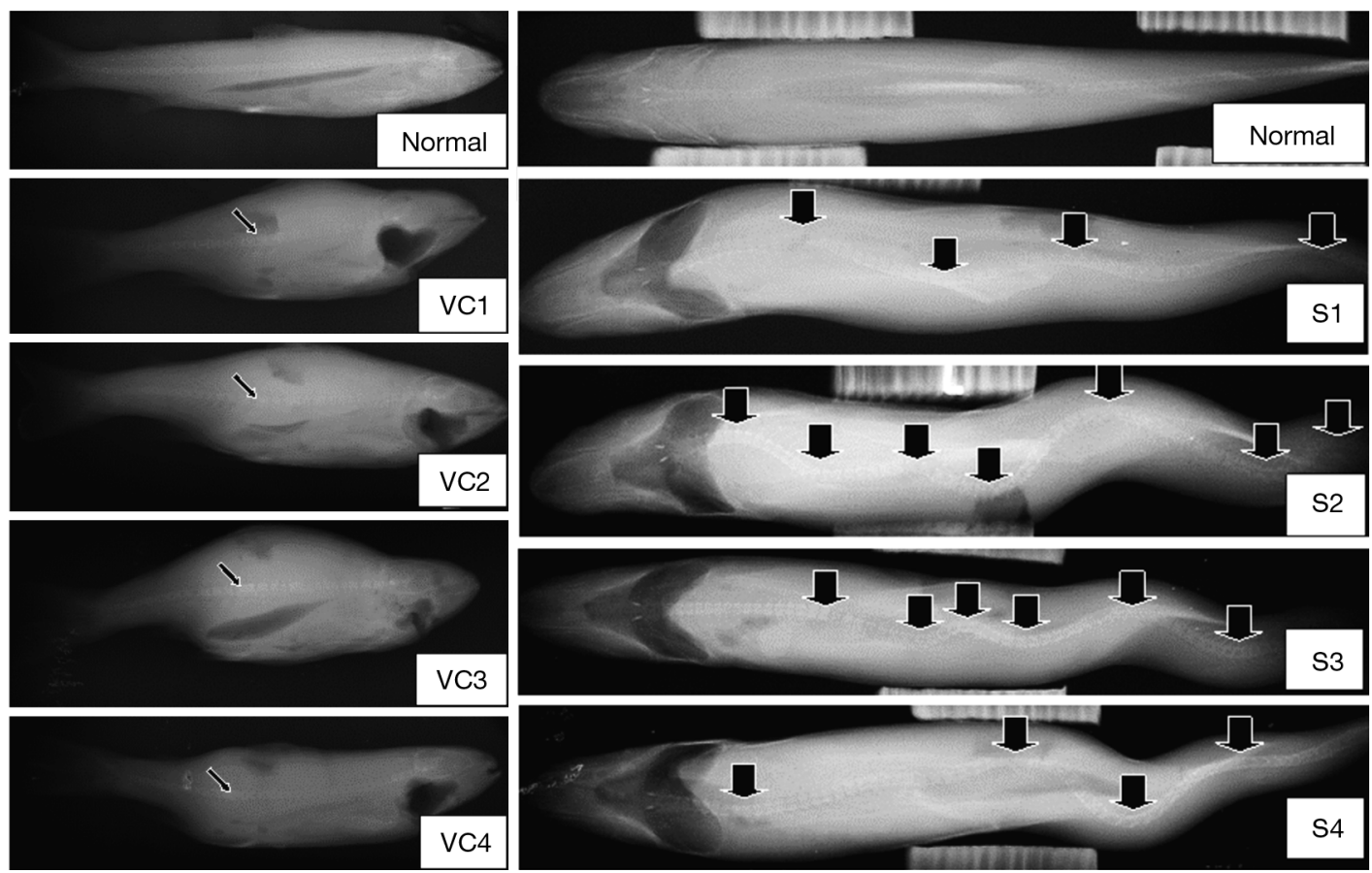

Fig. 1. Salmo salar. X-ray examination of the spines of a representative normal (non-deformed) subject and 4 fish showing vertebral compression (VC1 to VC4) and 4 with scoliosis (S1 to S4). Vertebral compression/fusion fish and representative normal fish were X-rayed from the lateral side and a thin arrow indicates the location of the fused vertebrae. Scoliotic and representative normal fish were X-rayed from the ventral side where thick arrows represent points of spinal curvature 
anaerobic capacity tests. As a result of this variation, the results from individual fish have been presented as well as mean values from the fish tested (Table 1).

\section{Swimming performance}

In general, fish with vertebral fusion appeared smaller than the scoliotic fish and normal triploids by mass as well as fork length, although due to variation this was not statistically significant (length: $F_{2,14}=$ 3.786, $p=0.0530$; mass: $F_{2,14}=0.607, p=0.5210$ ). There were significant differences between the fish groups tested in terms of both first and second critical swimspeed tests $\left(U_{\text {crit } 1}: F_{2,14}=17.770, \mathrm{p}<0.0001 ; U_{\text {crit2 }}\right.$ : $\left.F_{2,14}=23.564, \mathrm{p}<0.0001\right)$. Fish with vertebral compression attained critical swimming speeds equivalent to those of normal fish for both $U_{\text {crit1 }}$ and $U_{\text {crit2 }}$ ( $\left.p>0.05\right)$. Scoliotic fish, on the other hand, were significantly poorer swimmers, attaining critical swimming speeds 46 and $40 \%$ that of normal controls for $U_{\text {crit1 }}$ and $U_{\text {crit2 }}$, respectively $(p<0.05)$ (Table 1$)$. The ability to recover from swimming exercise (RR) was not significantly different between the groups tested $\left(F_{2,14}=2.880, \mathrm{p}=\right.$ 0.0950), with all 3 groups of fish having an RR similar to 1. However, in scoliotic fish, there was a general trend for RR to be lower, with RR on average being $13 \%$ lower than that for normal non-deformed controls (Table 1, Fig. 2).

\section{Recovery from exhaustive exercise}

$\mathrm{MO}_{2 \text { rout }}$ was significantly different between the 3 groups of fish, with normal fish having a significantly lower $\mathrm{MO}_{2 \text { rout }}$ compared with fish with either vertebral fusion or scoliosis $\left(F_{2,14}=9.148, \mathrm{p}=0.0040\right)$. Similarly, normal fish had a significantly lower $\mathrm{MO}_{2 \max }$ compared with fish with vertebral fusion but not compared with scoliotic fish $\left(F_{2,14}=10.241, \mathrm{p}=0.030\right)$ (Table 1$)$. The routine metabolic scope showed a significant difference between fish groups $\left(F_{2,14}=4.119, \mathrm{p}=0.0043\right)$, with fish with vertebral fusion having a larger scope compared with normal fish, but no diference was detected between scoliotic fish in comparison to fish with vertebral fusion or the normal controls (Table 1). EPOC was significantly different between fish groups $\left(F_{2,11}=4.452, \mathrm{p}=0.045\right)$, with normal fish requiring more oxygen $(44 \%$ more than fish with vertebral compression and $101 \%$ more than scoliotic fish) to repay the oxygen debt and replenish metabolic energy stores (Table 1). The time in which this EPOC occurred was

Table 1. Salmo salar. Individual and mean (bold) swimming performance and recovery from exhaustive exercise of triploid smolts which were normal (non-deformed), deformed by vertebral fusion, or scoliotic $U_{\text {crit1, }} U_{\text {crit2 }}$ : critical swimming speed for the first and second tests; RR: recovery ratio; $\mathrm{MO}_{2 \text { rout }}$ and $\mathrm{MO}_{2 \max }$ : routine and maximum recovery rate; Scope: relative metabolic scope $\left(\mathrm{MO}_{2 \max }-\mathrm{MO}_{2 \text { rout }}\right)$; EPOC: post exercise oxygen consumption; Time: time for consumption of EPOC. BL: body length; nd: not determined. Superscripts indicate significant differences

\begin{tabular}{|c|c|c|c|c|c|c|c|c|}
\hline Deformity & $\begin{array}{c}U_{\text {crit1 }} \\
\left(\mathrm{BL}^{-1}\right)\end{array}$ & $\begin{array}{c}U_{\text {crit2 }} \\
\left(\mathrm{BL}^{-1}\right)\end{array}$ & $\mathrm{RR}$ & $\begin{array}{c}\mathrm{MO}_{2 \text { rout }} \\
\left(\mu \mathrm{M} \mathrm{g}^{-1} \mathrm{~h}^{-1}\right)\end{array}$ & $\begin{array}{c}\mathrm{MO}_{2 \max } \\
\left(\mu \mathrm{M} \mathrm{g}^{-1} \mathrm{~h}^{-1}\right)\end{array}$ & $\begin{array}{c}\text { Scope } \\
\left(\mu \mathrm{M} \mathrm{g}^{-1} \mathrm{~h}^{-1}\right)\end{array}$ & $\begin{array}{c}\text { EPOC } \\
\left(\mu \mathrm{M} \mathrm{g}^{-1}\right)\end{array}$ & $\begin{array}{l}\text { Time } \\
\text { (min) }\end{array}$ \\
\hline None & 3.13 & 3.13 & 1.00 & 3.11 & 8.09 & 4.98 & 18.17 & 480 \\
\hline None & 3.11 & 3.08 & 0.99 & 3.60 & 13.19 & 9.59 & 10.28 & 290 \\
\hline None & 3.06 & 3.04 & 0.99 & 2.24 & 13.54 & 11.30 & 25.54 & 480 \\
\hline None & 2.27 & 2.20 & 0.97 & 4.95 & 10.87 & 5.92 & 11.65 & 175 \\
\hline None & 3.13 & 3.13 & 1.00 & 3.66 & 8.27 & 4.61 & nd & nd \\
\hline None & 3.26 & 3.42 & 1.05 & 3.46 & 8.50 & 5.04 & nd & nd \\
\hline None & 2.36 & 2.21 & 0.93 & 3.83 & 8.90 & 5.07 & nd & nd \\
\hline Mean & $2.90^{\mathrm{a}}$ & $2.89^{a}$ & 0.99 & $3.55^{\mathrm{a}}$ & $10.19^{a}$ & $6.64^{\mathrm{a}}$ & $16.41^{\mathrm{a}}$ & 356 \\
\hline SEM & 0.15 & 0.18 & 0.01 & 0.31 & 0.89 & 1.01 & 3.03 & 65 \\
\hline Vertebral fusion & 2.84 & 2.81 & 0.99 & 5.21 & 13.76 & 8.55 & 5.98 & 110 \\
\hline Vertebral fusion & 2.88 & 2.81 & 0.97 & 4.90 & 14.78 & 9.88 & 12.76 & 210 \\
\hline Vertebral fusion & 1.63 & 2.18 & 1.34 & 4.18 & 17.29 & 13.11 & 12.50 & 330 \\
\hline Vertebral fusion & 2.47 & 2.19 & 0.89 & 6.48 & 16.90 & 10.42 & 21.83 & 360 \\
\hline Mean & $2.46^{\mathrm{a}}$ & $2.50^{\mathrm{a}}$ & 1.05 & $5.19^{b}$ & $15.68^{b}$ & $10.49^{b}$ & $13.27^{a b}$ & 252 \\
\hline SEM & 0.25 & 0.16 & 0.09 & 0.41 & 0.73 & 0.83 & 2.82 & 49 \\
\hline Scoliosis & 1.39 & 1.10 & 0.79 & 5.47 & 13.58 & 8.11 & 3.69 & 130 \\
\hline Scoliosis & 1.09 & 0.86 & 0.79 & 6.68 & 14.18 & 7.50 & 2.21 & 40 \\
\hline Scoliosis & 1.52 & 1.38 & 0.91 & 4.58 & 12.30 & 7.72 & 9.81 & 285 \\
\hline Scoliosis & 1.37 & 1.32 & 0.97 & 6.06 & 11.68 & 5.63 & 1.76 & 30 \\
\hline Mean & $1.34^{b}$ & $1.16^{b}$ & 0.86 & $5.70^{b}$ & $12.94^{\mathrm{ab}}$ & $7.24^{\mathrm{ab}}$ & $4.37^{b}$ & 121 \\
\hline SEM & 0.08 & 0.10 & 0.04 & 0.39 & 0.50 & 0.48 & 1.61 & 51 \\
\hline
\end{tabular}




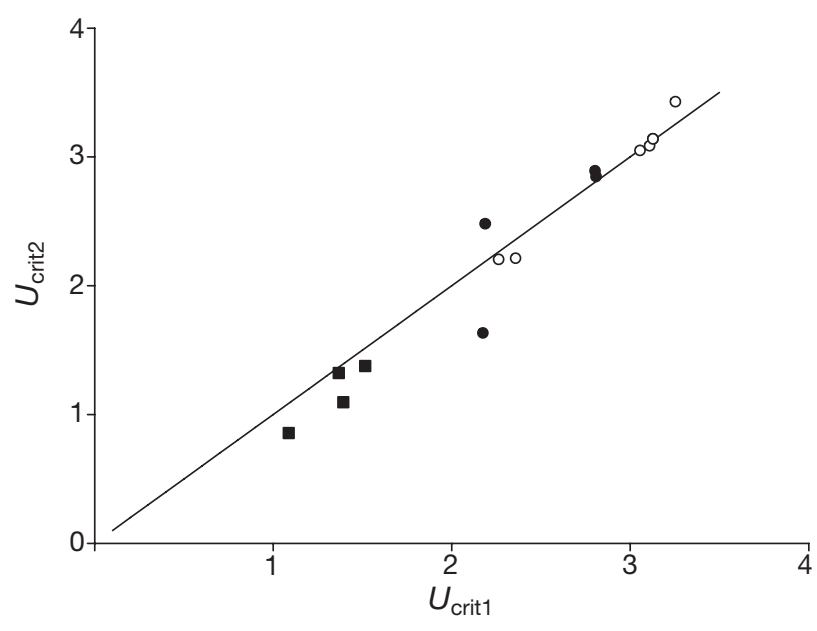

Fig. 2. Salmo salar. Relationship between the critical swimming speeds for the first and second tests $U_{\text {crit2 }}$ and $U_{\text {crit1 }}$ for normal (O), vertebral compression (๑) and scoliotic (ם) fish. Solid line represents the line of identity where the recovery ratio $\left(U_{\text {crit } 2}: U_{\text {crit1 }}\right)$ equals 1

not significantly different between groups $\left(F_{2,11}=\right.$ 3.343, $\mathrm{p}=0.082$ ) owing to high variability. However, the trend was for deformed fish to recover their oxygen consumption to pre-exercise levels quicker than normal fish (Table 1).

\section{DISCUSSION}

Fish with vertebral fusion were able to swim at speeds relative to BL equivalent to those of normal, non-deformed fish. However, since fish with vertebral fusion were generally shorter than normal fish, this would suggest that the absolute swimming speed $\left(\mathrm{cm} \mathrm{s}^{-1}\right)$ was lower for fish with vertebral fusion compared with normal controls. The consequences of this would be that fish with vertebral fusion-type skeletal deformities would be less likely to sustain swimming in a current or avoid predation than non-deformed fish. The critical swimming speed of scoliotic fish was significantly lower than that of controls and, given the similar relative length of the scoliotic fish compared with normal fish, this would suggest that this reduced critical swim speed would also translate to a reduced absolute swimming velocity $\left(\mathrm{cm} \mathrm{s}^{-1}\right)$ prior to exhaustion. It would be reasonable to assume that scoliotic deformed fish, like fish with vertebral fusion, would be less likely to maintain their position in a current or avoid predation compared with their non-deformed counterparts.

The use of a repeat swim test after a defined recovery period is a useful tool for assessing fish health performance and the effects of disease (Jain et al. 1998,
Wagner et al. 2003, Tierney \& Farrell 2004, Tierney et al. 2005). In the present study it would appear that the different deformities produced no statistically significant difference in RR compared to normal fish. However, this was probably a reflection of the relatively low sample size (statistical power for this test was 0.307 compared with 0.484 to 1.000 where significant differences occurred). There was a pronounced trend for reduced $\mathrm{RR}$ in scoliotic fish compared with fish with vertebral fusion or the non-deformed controls. This suggested that scoliotic fish were probably unable to satisfactorily recover from exhaustive swimming within the 45 min recovery period compared with the other fish tested. The failure of fish to recover from exhaustive swimming can be attributed to a number of different factors, although the clearance of lactate and recovery of oxygen stores are likely to be the most limiting. Lijalad \& Powell (2009) suggested that Atlantic salmon with lower jaw deformities may be compromised by the lack of water flow over their gills, whereas Powell et al. (2008) have suggested that Atlantic salmon with gills compromised by amoebic parasitic infections may have limited swimming performance and recovery because of gill surface area and/or cardiovascular compromise.

The $\mathrm{MO}_{2 \text { rout }}$ of fish with vertebral fusion and scoliotic fish were elevated compared with normal fish. However, the $\mathrm{MO}_{2 \max }$ was statistically higher only in fish with vertebral fusion compared with normal controls, although there was a trend for increased maximal oxygen consumption in both groups of deformed fish. The consequence of this increased routine cost is offset by the increased $\mathrm{MO}_{2 \max }$ to ensure that routine metabolic scope is maintained or even increased (in the case of the vertebral fusion deformity). Whereas in some species, metabolic scope is defended despite the fish being diseased (Powell et al. 2005), infectious disease in Atlantic salmon appears to generally result in a decrease in metabolic scope (Jones et al. 2007, Leef et al. 2007), reflecting a reduction in the energy potentially available for growth. This does not appear to be the case for non-infectious skeletal deformities. The reason for this increase in $\mathrm{MO}_{2 \text { rout }}$ in skeletally deformed fish in the present study is unclear since previous studies found no difference in metabolic rate between normal Atlantic salmon and those exhibiting a lower jaw deformity (Lijalad \& Powell 2009). However, there may be an increased cost of maintaining position within the water column imposed by spinal deformity, which may be reflected in this increase in $\mathrm{MO}_{2 \text { rout }}$ Increases in $\mathrm{MO}_{2 \max }$ have been seen in parasitized trout, ensuring maintenance of metabolic scope (Powell et al. 2005), and this may be similarly reflected in the present study. 
Interestingly, EPOC was lower and the repayment of this 'oxygen debt' was quicker in deformed versus control fish. This phenomenon has also been observed for lower jaw deformities in Atlantic salmon (Lijalad 2006, Lijalad \& Powell 2009) and would appear at odds with the data from swimming performance tests in which scoliotic fish appeared to fail to recover from exhaustive swimming as well as the other groups did. However, a possible uniting explanation is that fish with skeletal deformities are incapable of sustaining anaerobic activity, and thus do not enter into anaerobiosis. This would result in a lower EPOC and apparently faster recovery. It is tempting to speculate that these data may also suggest that fish with skeletal deformities are indeed more capable of clearing anaerobic metabolites, perhaps due to a need to continue swimming after exhaustion, as seen in other studies (Milligan et al. 2000). Interestingly, Lijalad \& Powell (2009) showed a similar response in triploid Atlantic salmon with a lower jaw deformity. However, we have no evidence suggesting that fish with skeletal deformities can either clear anaerobic metabolites faster than normal fish or have a requirement for maintaining swimming activity post-exhaustion.

\section{CONCLUSIONS}

The present study characterised the physiological impacts of 2 spinal deformities in triploid Atlantic salmon as they affect swimming performance testing. It would appear that although both spinal deformities may affect the absolute speed at which fish are able to swim, only scoliosis impairs critical swimming speed. However, the physiological cost of deformity is such that there is an impost on routine and maximal metabolic rate in deformed fish, which reduces routine metabolic scope. It would appear that deformed fish may lack the capacity for anaerobic activity, which likely makes these fish more vulnerable under wild conditions to predation or limit breeding-age fish from being able to ascend high velocity water features.

Acknowledgements. We thank J. Ransome for assistance with fish maintenance, H. King (SALTAS) for the supply of fish, C. G. Carter for use of X-ray equipment and K. Irwin for assistance with X-raying of the fish carcasses.

\section{LITERATURE CITED}

Alsop DH, Wood CM (1997) The interactive effects of feeding and exercise on oxygen consumption, swimming performance and protein use in juvenile rainbow trout (Oncorhynchus mykiss). J Exp Biol 200:2337-2346

Altimiras J, Axelsson M, Claireaux C, LeFrancois C, Mercier C, Farrell AP (2002) Cardiorespiratory status of triploid brown trout during swimming at two acclimation temperatures. J Fish Biol 60:102-116
Aunsmo A, Guttvik A, Midtlyng PJ, Larssen RB, Evensen $\varnothing$, Skjerve E (2008) Association of spinal deformity and vaccine-induced abdominal lesions in harvest sized Atlantic salmon, Salmo salar L. J Fish Dis 31:515-524

Baeverfjord G, Lein I, Asgard T, Rye M (1997) Shortened operculae in Atlantic salmon Salmo salar L. fry reared at high temperatures. Proc 8th Int Eur Assoc Fish Pathol Conf, Edinburgh, p 15

Beamish FWH, Howlett JC, Medland TE (1989) Impact of diet on metabolism and swimming performance in juvenile lake trout, Salvelinus namaycush. Can J Fish Aquat Sci 46:384-388

Benfey TJ, Sutterlin AM, Thompson RJ (1984) Use of erythrocyte measurements to identify triploid salmonids. Can J Fish Aquat Sci 41:980-984

Boutilier RG, Heming TA, Iwama GK (1984) Physiochemical parameters for use in fish respiratory physiology. In: Hoar WS, Randall DJ (eds) Fish physiology. Academic Press, New York, NY, p 401-430

Branson EJ, Nieto D (1999) Jaw deformities in Atlantic salmon (Salmo salar) in Chile. Proc 9th Int Eur Assoc Fish Pathol Conf, Rhodes, p 31

Brett J (1964) The respiratory metabolism and swimming performance of young sockeye salmon. J Fish Res Board Can 21:1184-1226

Bruno DW (1990) Jaw deformity associated with farmed Atlantic salmon (Salmo salar). Vet Rec 126:402-403

Cameron JN (1986) Principles of physiological measurement. Academic Press, London

> Deschamps MH, Kacem A, Ventura R, Courty G, Haffray P, Meunier FJ, Sire JY (2008) Assessment of 'discreet' vertebral abnormalities, bone mineralization and bone compactness in farmed rainbow trout. Aquaculture 279:11-17

Farlinger S, Beamish FWH (1978) Changes in blood chemistry and critical swimming speed of largemouth bass, Micropterus salmoides, with physical conditioning. Trans Am Fish Soc 107:523-527

> Farrell AP, Gamperl AK, Birtwell K (1998) Prolonged swimming, recovery and repeat swimming performance of mature sockeye salmon Oncorhynchus nerka exposed to moderate hypoxia and pentachlorophenol. J Exp Biol 201:2183-2193

Gionechea O, Enriquez R, Paredes E, Molinari E (1999) Jaw and other skeletal deformities in Chilean farmed Atlantic salmon (Salmo salar). Proc 9th Int Eur Assoc Fish Pathol Conf, Rhodes, Greece, p 31

Hughes D (1992) Lower jaw deformity in farmed Tasmanian Atlantic salmon Salmo salar (Salmoniformes, Teleostei). Final report. Barriers and breakthroughs. In: Valentine P (ed) 1992 SALTAS research and development seminar. SALTAS, Hobart, TAS, p 17-64

> Hyndman CA, Keiffer JD, Benfey TJ (2003) The physiological response of diploid and triploid brook trout to exhaustive exercise. Comp Biochem Physiol A 134:167-179

Jain KE, Hamilton JC, Farrell AP (1997) Use of ramp velocity test to measure critical swimming speed in rainbow trout (Oncorhynchus mykiss). Comp Biochem Physiol A 117:441-444

> Jain KE, Birtwell IK, Farrell AP (1998) Repeat swimming performance of mature sockeye salmon following a brief recovery period: a proposed measure of fish health and water quality. Can J Zool 76:1488-1496

Johnstone R, McLay HA, Walsingham MV (1991) Production and performance of triploid Atlantic salmon in Scotland. In: Pepper VA (ed) Proc Atlantic Canada Workshop on methods for the production of non-maturing salmonids. Department of Fisheries and Oceans Canada, St. John's, NL, p 15-33 
Jones DR, Kiceniuk W, Banford OS (1974) Evaluation of the swimming performance of several fish species from the Mackenzie river. J Fish Res Board Can 31:1641-1647

> Jones MA, Powell MD, Becker JA, Carter CG (2007) Effect of an acute necrotic bacterial gill infection and feed deprivation on the metabolic rate of Atlantic salmon Salmo salar. Dis Aquat Org 78:29-36

Jungalwalla P (1991) Production of non-maturing Atlantic salmon in Tasmania. In: Pepper VA (ed) Proc Atlantic Canada workshop on methods for the production of nonmaturing salmonids. Department of Fisheries and Oceans Canada, St. John's, NL, p 47-71

Kieffer JD, Currie S, Tufts BL (1994) Effects of environmental temperature on the metabolic and acid-base responses of rainbow trout to exhaustive exercise. J Exp Biol 194: 299-317

King H, Lee P (1993) Progress report: jaw deformity and respiratory physiology of triploids. In: Valentine P (ed) Seeking and solving, SALTAS research and development review seminar. SALTAS, Hobart, TAS, p 37-44

Lall SP, Lewis-McCrea LM (2007) Role of nutrients in skeletal metabolism and pathology in fish - an overview. Aquaculture 267:3-19

Lee P, King H (1994) Effects of reduced dietary energy on the incidence of jaw deformity in Tasmanian Atlantic salmon. In: Valentine P (ed) SALTAS research and development programme. SALTAS, Hobart, TAS, p 61-69

Leef MJ, Harris JO, Powell MD (2007) Metabolic effects of amoebic gill disease (AGD) and chloramine-T exposure in seawater-acclimated Atlantic salmon Salmo salar. Dis Aquat Org 78:37-44

Lijalad M (2006) Effects of ploidy status and lower jaw deformity syndrome (LJD) on the exercise physiology and Atlantic salmon (Salmo salar L.). B Aqua honours thesis, University of Tasmania, Launceston

Lijalad M, Powell MD (2009) Effects of lower jaw deformity on swimming performance and recovery from exhaustive exercise in triploid and diploid Atlantic salmon, Salmo salar L. Aquaculture 290:145-154

McGeachy SA, O'Flynn FM, Benfey TJ, Friars GW (1996) Seawater performance of triploid Atlantic salmon in New Brunswick aquaculture. Bull Aquac Assoc Can 2:24-28

McKay LR, Gjerde B (1986) Genetic variation for a spinal deformity in Atlantic salmon Salmo salar. Aquaculture 52:263-272

Milligan CL (1996) Metabolic recovery from exhaustive exercise in rainbow trout. Comp Biochem Physiol A 113:51-60

Milligan CL, Hooke GB, Johnson C (2000) Sustained swimming at low velocity following a bout of exhaustive exercise enhances metabolic recovery in rainbow trout. J Exp Biol 203:921-926

Oakland F, Finstad B, McKinley RS, Thorstad EB, Booth JH (1997) Radio-transmitted electromyogram signals as indicators of physical activity in Atlantic salmon. J Fish Biol 51:476-488

Ornsrud R, Wargelius A, Saele O, Pittman K, Waagbo R (2004) Influence of egg vitamin A status and egg incubation temperature on subsequent development of the early

Editorial responsibility: Roland Anderson,

Seattle, Washington, USA vertebral column in Atlantic salmon fry. J Fish Biol 64: 399-417

Powell MD, Speare DJ, Daley J, Lovy J (2005) Difference in metabolic responses to Loma salmonae infection in juvenile rainbow trout Oncorhynchus mykiss and brook trout Salvelinus fontinalis. Dis Aquat Org 67:233-237

> Powell MD, Leef MJ, Roberts SD, Jones MA (2008) Neoparamoebic gill infections: host response and physiology in salmonids. J Fish Biol 73:2161-2183

Quigley DTG (1995) A lower jaw deformity in juvenile and adult Atlantic salmon (Salmo salar L). Bull Eur Assoc Fish Pathol 15:206-208

Reidy SP, Nelson JA, Tang Y, Kerr SR (1995) Post-exercise metabolic rate in Atlantic cod and its dependence upon the method of exhaustion. J Fish Biol 47:377-386

> Roberts RJ, Hardy RW, Sugiura SH (2001) Screamer disease in Atlantic salmon, Salmo salar L. in Chile. J Fish Dis 24: 543-549

Ross LG, McKinney RW, Cardwell SK, Fullarton JG, Roberts SEJ, Ross B (1992) The effects of dietary protein content, lipid content and ration level on oxygen consumption and specific dynamic action in Oreochromis niloticus L. Comp Biochem Physiol A 103:573-578

Sadler J, Pankhurst NW, Pankhurst PM, King H (2000) Physiological stress responses to confinement in diploid and triploid Atlantic salmon. J Fish Biol 56:506-518

> Small SA, Randall DJ (1989) Effects of triploidy on the swimming performance of coho salmon (Oncorhynchus kisutch). Can J Fish Aquat Sci 46:243-245

Stillwell EJ, Benfey TJ (1996) Haemoglobin level, metabolic rate, opercular abduction rate and swimming efficiency in female triploid brook trout (Salvelinus fontinalis). Fish Physiol Biochem 15:377-383

Summerfelt RC, Smith LS (1990) Anesthesia, surgery and related techniques. In: Schreck CB, Moyle PB (eds) Methods for fish biology. American Fisheries Society, Bethesda, MD, p 213-272

Sutterlin AM, Holder J, Benfey TJ (1987) Early survival and subsequent morphological deformities in landlocked, anadromous, and hybrid (landlocked $\times$ anadromous) diploid and triploid Atlantic salmon. Aquaculture 64: $157-164$

Thomas CW, Carter CG, Crear BJ (2002) Potential use of radiography for measuring feed intake of southern rock lobster (Jasus edwardsii). J Exp Mar Biol Ecol 273:189-198

Thomas P, Morrison R (1995) A method to assess triploidy in swim-up rainbow trout. Austasia Aquac 9:61-63

> Tierney KB, Farrell AP (2004) The relationships between fish health, metabolic rate, swimming performance and recovery in return-run sockeye salmon, Oncorhynchus nerka (Walbaum). J Fish Dis 27:663-671

Tierney KB, Balfry SK, Farrell AP (2005) Subclinical Listonella anquillarum infection does not impair recovery of swimming performance in rainbow trout Oncorhynchus mykiss. Dis Aquat Org 67:81-86

Wagner GN, McKinley RS, Bjorn PA, Finstad B (2003) Physiological impact of sealice on swimming performance of Atlantic salmon. J Fish Biol 62:1000-1009

Submitted: October 29, 2008; Accepted: March 2, 2009

Proofs received from author(s): April 21, 2009 